\title{
Ethnobotanical Survey of Medicinal Plants Used for the Treatment of Diabetes in the Tizi n' Test Region (Taroudant Province, Morocco)
}

\author{
Abderrahmaine Katiri ${ }^{1}$, Mohamed Barkaoui ${ }^{1}$, Fouad Msanda ${ }^{1}$ and Hassan Boubaker ${ }^{2 *}$ \\ ${ }^{1}$ Laboratory of Biotechnologies and Valorization of Natural Resources, Ibn Zohr University, BP 8106, Agadir, Morocco \\ ${ }^{2}$ Laboratory of Microbial Biotechnologies and Plant Protection, Ibn Zohr University, Agadir, Morocco
}

\begin{abstract}
In Morocco, diabetes mellitus is a major public health problem with over than 1.5 million cases in 2014 Medicinal plants are widely used by the Moroccan population to treat the illness. This study was carried out to identify the medicinal plants traditionally used in human therapy to treat diabetes in the Tizi n'Test region, and contribute to safeguarding knowledge and local expertise in traditional herbal medicine. A total of 280 interviews were conducted with traditional health practitioners and knowledgeable villagers. Data were collected by semistructured and structured questionnaires. Indices on Fidelity Level (FL), Use Value (UV) and Relative Frequency of Citation (RFC) were calculated. The ethnobotanical survey has identified 39 species representing 24 families. The most encountered medicinal plant families were Asteraceae and Lamiaceae. The following plant species were showed the high significant FL, UV and RFC: Artemisia herba-alba, Cistus creticus, Lavandula maroccana, Salvia lavandulifolia and Olea europaea. Plant leaves were the most commonly used plant part, and decoction was the most common method of traditional drug preparation. Our study showed that medicinal plants continue to play an important role in the primary healthcare system for the local population of the Tizi n'Test region and represents a useful documentation, which can contribute to preserving knowledge on the use of medicinal plants for diabetes treatment and to explore the phytochemical and pharmacological potential of medicinal plant.
\end{abstract}

Keywords: Ethnobotanical survey; Medicinal plants; Traditional medicine; Tizi n'Test region; Morocco

\section{Introduction}

Diabetes mellitus is a chronic metabolic disorder of multiple etiologies characterized by hyperglycemia with disturbances of carbohydrate, fat and protein metabolism resulting from defects in insulin secretion, insulin action or both [1]. According to the International Diabetes Federation (IDF) there were 415 million people in the world with diabetes and this is projected to increase to 642 million by 2040 [2]. In Morocco, diabetes mellitus is one of the most common metabolic diseases, there were over 1.4 million cases of diabetes in 2013 [3]. Due to socio-economic and cultural factors, people in rural regions of developing countries exploit a variety of medicinal plants for the effective treatment of various diseases. According to WHO, about $80 \%$ of the world's population, essentially in developing countries, depends on medicinal plants to meet their primary healthcare needs [4]. In a survey in eastern Morocco, about $60 \%$ of non-insulin-dependent diabetics were found to resort to the use of medicinal plants to treat their disease [5,6]. Furthermore, the diabetes mellitus is one of the most common metabolic diseases in Morocco. Indeed, its prevalence ranges between $10 \%$ in rural areas and $13.3 \%$ in urban areas.

In Morocco, as much as $50 \%$ of the population resides in rural areas where access to modern health care facilities is lacking; furthermore, this access is more difficult if the medium is mountainous. Following these conditions, local people rely more heavily on traditional medicinal plants than on western drug. Morocco is known for its rich vegetation and plant biodiversity [7] and it is also one of the Mediterranean countries with a long medical tradition and ancestral knowhow of herbal medicine [8]. Traditional medicinal plants have several advantages, they are locally available and more easily accessible, there is no evidence of resistance to whole-plant extracts and are frequently considered being less toxic and free from side effects as western drug $[9,10]$.

In several parts of the world, the knowledge of the use of medicinal plants and the procedures applied to their preparation is usually transmitted from generation to generation by word of mouth rather than in writing, facing extinction if it is not recorded [11]. Also, factors such as migration, the rural exodus, expertise loss due to death of the elderly, acculturation, alteration of physical and biological environments, etc. are causing a rapid loss of traditional knowledge, which would make such studies primordial [12]. Therefore, in this study, we have done a survey of use of antidiabetic plants by Tizi n'test population, in order to contribute to the safeguarding of knowledge and local expertise and, on the other hand, to review the scientific data aiming at correlation between popular use and biological properties of medicinal plants.

\section{Materials and Methods}

\section{Study area}

The study was carried out in 7 rural communes (Tizi n'Test, Ouneine, Tafingoult, Sidi Ouaaziz, Ida-Ougoummad, Tisrass and Ouzioua) who are situated in the southern Moroccan; province of Taroudant. The study area is located at about $90 \mathrm{~km}$ North East of Taroudant center. Geographically the area corresponds to the southern slope of the western High Atlas. The study site has 300-700

${ }^{*}$ Corresponding author: Hassan Boubaker, Faculty of Science, Laboratory of Microbial Biotechnologies and Plant Protection, Ibn Zohr University, P.O. Box 8106, Agadir, Morocco, Tel: 2120528 220957; Fax: 2120528220100; E-mail: h.boubaker@uiz.ac.ma

Received October 31, 2016; Accepted November 28, 2016; Published January 02, 2017

Citation: Katiri A, Barkaoui M, Msanda F, Boubaker H (2017) Ethnobotanical Survey of Medicinal Plants Used for the Treatment of Diabetes in the Tizi n' Test Region (Taroudant Province, Morocco). J Pharmacogn Nat Prod 3: 130. doi: 10.4172/2472-0992.1000130

Copyright: (๑) 2017 Katiri A, et al. This is an open-access article distributed under the terms of the Creative Commons Attribution License, which permits unrestricted use, distribution, and reproduction in any medium, provided the original author and source are credited. 
mm mean annual rainfall. The Rainfall occurs mainly in autumn and winter. The snow, when it falls, can reach $1 \mathrm{~m}$ in high altitude and barely $5 \mathrm{~cm}$ in the plain. The average monthly temperatures range from $5.4^{\circ} \mathrm{C}$ in December and $24^{\circ} \mathrm{C}$ in July and August. Tizi n'Test region is characterized by a Mediterranean climate and semi-arid bioclimate, with altitudinal variations from 720-3000 masl (Figure 1). The Tizi n'Test region has characteristic vegetation dominated by shrubby and trees plant communities. The region is mountainous with fragile ecosystems where local biodiversity plays an important role in meeting the basic daily needs of the rural peoples inhabiting this region. Agricultural production is a main activity of the people; it is characterized by a moderately diversified production, followed by animal breeding and beekeeping.

\section{Data collection}

The ethnobotanical survey was carried out from January 2013 to October 2015, during which we conducted 280 interviews in different localities of the region. The data were collected through semi-structured and structured interviews with people having knowledge of traditional medicine and with traditional healers (called "Achab") living in major cities (Taroudant, Marrakech) around the region, but originally from the region of the study. The people interviewed were either born or had been living in the region for more than 16 years. During the interview, fresh plants, dried pressed plants or plant pictures, were shown to the informants to avoid misunderstandings concerning identification of the plants and to motivate informants to answer questions. The medicinal plants listed in this inventory were only included if they satisfied two criteria: the herbal remedies handed down from oral tradition and only those plant species that could be directly identified and/or collected by the person interviewed are cited in this paper. Interviews were designed to record information about the plants used to treat diabetes mellitus and their local names, methods of preparation, parts of the plant used, administration of medicines and the demographic characteristics of the participants in the study.

A medicinal property was accepted as valid only if it was mentioned by at least five independent interviewees. The interviews and the discussions were held in Berber (Tachelhit), the dialectal language of Tizi n'Test region. The collected plants were identifying by using "Flora of Morocco" [13-15] and voucher specimens of each plant were deposited in herbarium of the laboratory of Biotechnology and Valorization of the Natural Resources, Faculty of Sciences, Ibn Zohr University, and Agadir, Morocco.

\section{Data analysis}

The ethnobotanical data generated were analyzed using quantitative indices, namely: Fidelity Level (FL), Use Value (UV), and Relative Frequency of Citation (RFC). This helped to establish a consensus on which species are effective to cure diabetes, as well as the species' relative importance, and enabled us to understand the extent of the potential utilization of each species.

\section{Fidelity Level}

FL indicates the percentage of informants claiming the use of a certain plant species for the same major purpose. Fidelity level is calculated by the following formula:

$\mathrm{FL}(\%)=\mathrm{N}_{\mathrm{p}} / \mathrm{N} \times 100$, where $\mathrm{N}_{\mathrm{p}}$ is the number of informants that claimed a use of a plant species to treat a particular disease and $\mathrm{N}$ is the number of informants that used plants as a medicine to treat any given disease [16].

\section{Use Value (UV)}

The UV was calculated by using the following formula: $U V=\Sigma U / n$; Where $U$ is the number of use reports for a given plant species cited by each informant and $\mathrm{n}$ is the total number of informants interviewed for a given plant. The relative importance of plant species used in the traditional medicine can be determined by UV where most frequently cited plant species show a higher UV and plants with lesser citation show a lower UV [17].

\section{Relative Frequency of Citation (RFC)}

The RFC index was calculated on the basis of the following formula [18]: $\mathrm{RFC}=\mathrm{FC} / \mathrm{N}(0<\mathrm{RFC}<1)$.

Where FC is the number of informants who mentioned the use of the species and $\mathrm{N}$ is the total number of informants.

\section{Results and Discussion}

\section{Demographic characteristics of interviewees}

A total of 280 informants including traditional healers, herbalists and knowledgeable villagers participated in this study. 167 of respondents are women and 113 are men. 130 individuals depend on herbal medicine alone, 125 individuals use both herbal medicine and modern medicine and 25 people have recourse to modern medicine alone. Most of the local Tizi n'Test people were found to have some knowledge of diabetes mellitus based both on their ability to recognize a number of symptoms characteristic of the disease (such as excessive thirst, body weakness and frequent urination) and also on laboratory or hospital test results. The majority of people have opted for a traditional treatment because of its low cost and being accessible and affordable compared to modern medicine; that reflects the reality that local people have low incomes and therefore resort to traditional medicine that is cheap. Generally women had more knowledge of medicinal species by $65 \%$ against $35 \%$ for men. In contrast to men, women learn mainly from their mothers and grandmothers through routine observations. Similar findings were also reported in other parts of Morocco [5,1921] and elsewhere in the world [22,23]. The study showed that the frequency of medicinal plant use increased with age. The people older than 50 years of age have a frequency of use of medicinal plants by $57 \%$, followed by age categories ( 41 to 50$),(31$ to 40$),(21$ to 30 ) and finally the age of 20 with $18 \%, 13 \%, 8 \%$ and $4 \%$, respectively. This indicates that ethno-medicinal knowledge is mainly held by the elderly; similar findings were observed in other studies [24,25].

Interestingly, the frequency of use of medicinal plants was inversely related to the level of education of the interviewed population; illiterate: $75 \%$, primary education: $15 \%$, secondary education: $9 \%$ and university education: $1 \%$. The youngest respondents and people who studied up to the age of 20 or over were more inclined towards the modern medicines resulting in the loss of valuable herbal-based knowledge. Similar results were found in several studies [5,20,25-27].

\section{Medicinal plants used by the population}

The present ethnobotanical survey recorded information on 39 plant species, belonging to 24 families and 38 genera used to treat diabetes. These 39 plant species were cited by at least five separate informants (Table 1). The families with the most reported plant species were Asteraceae with 5 species (12.82\%), Lamiaceae with four species (10.25\%), Poaceae, Fabaceae and Rosaceae had three species each (7.69\%); Cistaceae and Apocynaceae had two species each (5.13\%), other families had 1 species each (2.56\%) (Figure 2). 


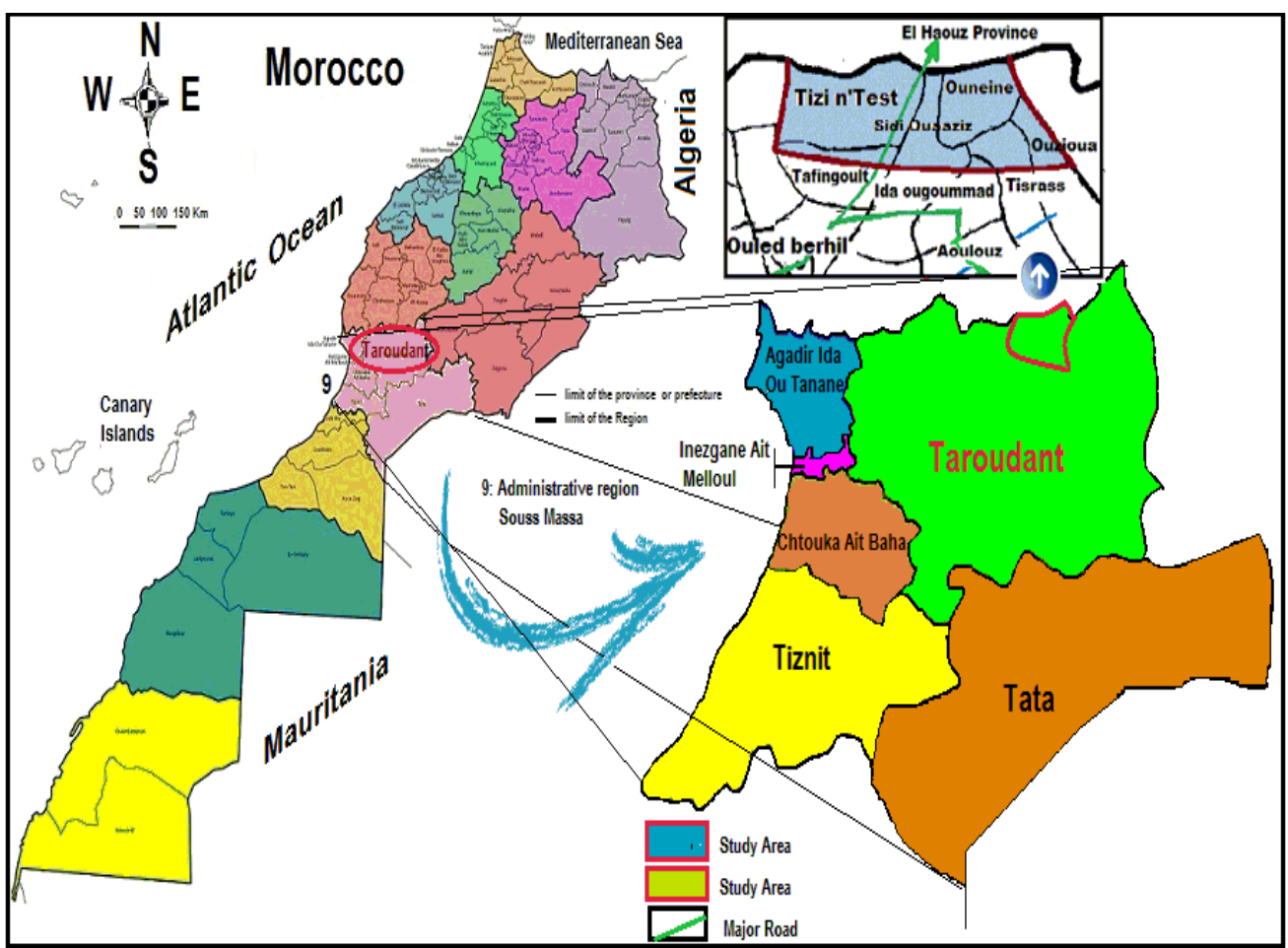

Figure 1: Location of the study area (Tizi n'Test region, North East of Taroudant).

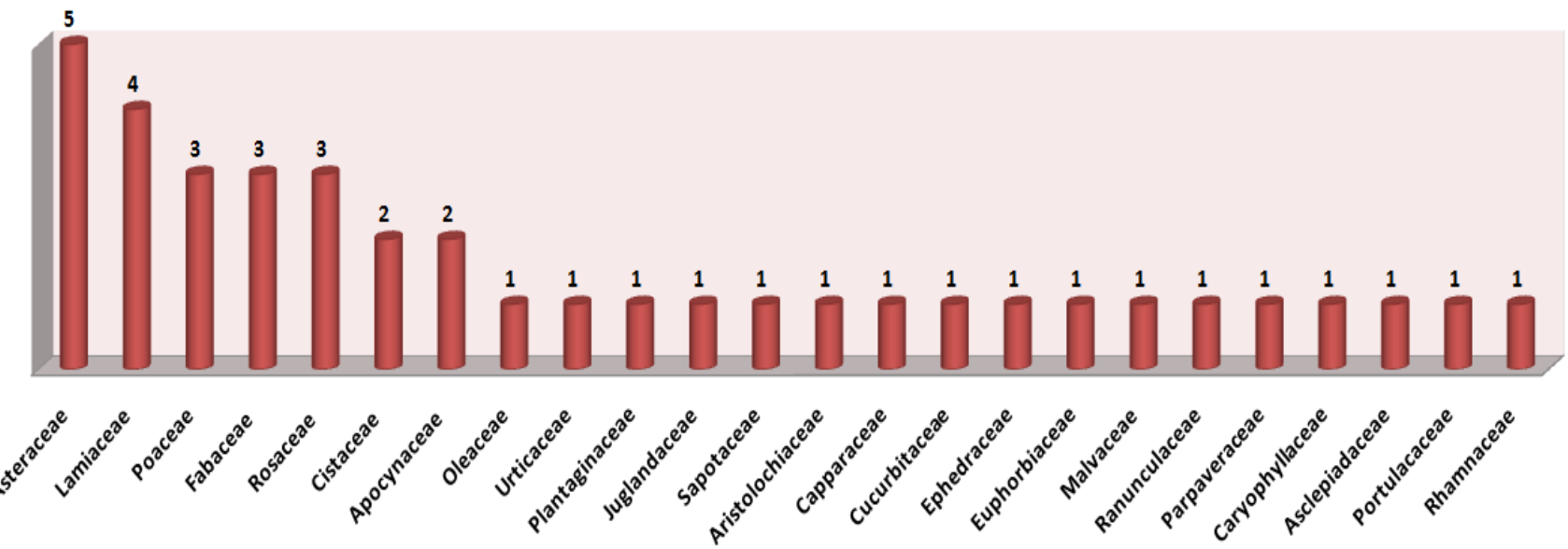

Figure 2: Number of medicinal species per botanical family.

The best two families which are well represented in the study area (Asteraceae and Lamiaceae), are also well distributed throughout Morocco, and also constitute the major groups of medicinal flora in most of other Mediterranean countries [22,28]. Asteraceae and Lamiaceae were also found among the predominant families in western Bengal in India [29]. Most of the families recorded are represented by single or two species which shows that medicinal plants used are not concentrated only in a few families and genera. This agrees with other ethnobotanical studies carried out in Morocco and in Mediterranean area [30-34].

The majority of medicinal plants $(69.23 \%)$ recorded in this survey were wild species and many species $(17.95 \%)$ are cultivated in the
Tizi n'Test region (Table 2). The large number of plant species used in the study area indicates a dependence on a great diversity of plant species to treat diabetes mellitus, and represents a good indicator of the profound knowledge on herbal plants held by the local people living in Tzi n’Test region.

The analysis of the biological forms of healing plants used to treat diabetes mellitus in the study area revealed that most of the species were herbs $(30.77 \%)$, followed by shrubs (25.64\%), subshrubs (15.39\%), trees and hemicryptophytes $(12.82 \%)$ and geophytes $(2.56 \%)$ (Figure 3). This agrees with another ethnobotanical study carried out in Morocco in which herbs were the most predominant growth form [24]. The most frequently mentioned medicinal plants to treat diabetes 
Citation: Katiri A, Barkaoui M, Msanda F, Boubaker H (2017) Ethnobotanical Survey of Medicinal Plants Used for the Treatment of Diabetes in the Tizi n' Test Region (Taroudant Province, Morocco). J Pharmacogn Nat Prod 3: 130. doi: 10.4172/2472-0992.1000130

Page 4 of 10

\begin{tabular}{|c|c|c|c|c|c|c|c|c|c|}
\hline $\begin{array}{l}\text { Families and plant } \\
\text { species }\end{array}$ & Vernacular name & Voucher & $\begin{array}{l}\text { Used } \\
\text { parts }\end{array}$ & Preparation & $\begin{array}{c}\text { Mode of } \\
\text { administration }\end{array}$ & UV & FL & RFC & Literature references \\
\hline $\begin{array}{c}\text { Apocynaceae } \\
\text { Caralluma europaea } \\
\text { (Guss.) N.E.Br.ssp. } \\
\text { maroccana (Hooker f.) } \\
\text { Maire. }\end{array}$ & $\begin{array}{l}\text { Aknariy nouzrou/ } \\
\text { Oukan }\end{array}$ & TSO3 & $\begin{array}{l}\text { Aerial } \\
\text { parts }\end{array}$ & Decoction & Oral & 1.28 & 38.46 & 0.7 & [84] \\
\hline Nerium oleander $\mathrm{L}$ & Allili/Dafla & TIZ19 & Leaf & Decoction & shower bath & 1.6 & 40.48 & 0.6 & $\begin{array}{c}{[5,6,20,21,24,33,38,53,54,84-} \\
86] .\end{array}$ \\
\hline $\begin{array}{c}\text { Aristolochiaceae } \\
\text { Aristolochia baetica } \mathrm{L}^{*}\end{array}$ & $\begin{array}{l}\text { Tiswik nigrane / } \\
\text { barztame }\end{array}$ & TIZ21 & Root & $\begin{array}{l}\text { Powder mixed } \\
\text { with honey }\end{array}$ & Oral & 0.96 & 34.09 & 0.16 & No reference \\
\hline $\begin{array}{c}\text { Asclepiadaceae } \\
\text { Periploca laevigata } \\
\text { Ait. }\end{array}$ & Asellif/Lhelab & TAF3 & Leaf & Decoction & Oral & 0.15 & 29.41 & 0.12 & {$[87]$} \\
\hline $\begin{array}{c}\text { Asteraceae } \\
\text { Artemisia herba alba } \\
\text { Asso }\end{array}$ & Izri/Chih & TIZ28 & $\begin{array}{l}\text { Leafy } \\
\text { stem }\end{array}$ & $\begin{array}{l}\text { Infusion/ } \\
\text { Tisane }\end{array}$ & Oral & 2.24 & 77.53 & 0.99 & {$[5,19,20,33,38,42,51-59,84-86]$} \\
\hline $\begin{array}{l}\text { Cladanthus scariosus } \\
\text { (Ball) Oberpr. \& Vogt" }\end{array}$ & Arzgi/irzgi & TIZ32 & Flower & Decoction & Oral & 0.19 & 48.15 & 0.1 & No reference \\
\hline Echinops spinosus L. & Taskra & TIZ35 & Root & Decoction & Oral & 1.25 & 21.43 & 0.15 & {$[6,24,39,84]$} \\
\hline Inula viscosa Aït & $\begin{array}{l}\text { Tinirine/ } \\
\text { Terrhla }\end{array}$ & TIZ36 & Leaf & Decoction & Oral & 1.05 & 37.57 & 0.62 & {$[21,38,54,84,86]$} \\
\hline $\begin{array}{c}\text { Scolymus hispanicus } \\
\mathrm{L}\end{array}$ & $\begin{array}{l}\text { Taggdut/ } \\
\text { L'gernina }\end{array}$ & TIZ40 & Root & Decoction & Oral & 0.21 & 45 & 0.14 & {$[6,84]$} \\
\hline $\begin{array}{c}\text { Capparaceae } \\
\text { Capparis spinosa } \mathrm{L}\end{array}$ & Taylilult/Lkebar & TIZ50 & Fruit & Decoction & Oral & 2.03 & 48.46 & 0.93 & {$[5,6,19,38,54,72,84,87]$} \\
\hline $\begin{array}{c}\text { Caryophyllaceae } \\
\text { Paronychia argentea } \\
\text { Lam }\end{array}$ & $\begin{array}{c}\text { Tahidourt } \\
\text { n'imksaoum }\end{array}$ & TON14 & $\begin{array}{l}\text { Leafy } \\
\text { stem }\end{array}$ & infusion & Oral & 0.15 & 29.03 & 0.11 & No reference \\
\hline $\begin{array}{c}\text { Cistaceae } \\
\text { Cistus creticus L }\end{array}$ & Ahnako/ Irgel & TIZ56 & Leaf & Decoction & Oral & 2.05 & 76.36 & 0.98 & [39] \\
\hline Cistus Laurifolius L & Hmiko/ Irgel & TIZ54 & Leaf & Decoction & Oral & 1.21 & 39.44 & 0.64 & {$[63,73,84]$} \\
\hline $\begin{array}{l}\text { Cucurbitaceae } \\
\text { Citrullus colocynthis } \\
\text { (L.) Schrader }\end{array}$ & Aferziz/Lhedja & TSO9 & Seed & Decoction & Oral & 0.19 & 22.22 & 0.06 & $\begin{array}{c}{[5,20,24,33,38,39,42,54,64-} \\
66,84,86,87]\end{array}$ \\
\hline $\begin{array}{c}\text { Ephedraceae } \\
\text { Ephedra fragilis desf }\end{array}$ & Amater & TIZ64 & $\begin{array}{l}\text { Leafy } \\
\text { stem }\end{array}$ & Decoction & Oral & 1.5 & 34.27 & 0.64 & No reference \\
\hline $\begin{array}{c}\text { Euphorbiaceae } \\
\text { Euphorbia resinifera } \\
\text { Berg }^{* *}\end{array}$ & Zaqoum & TSO12 & $\begin{array}{l}\text { Leafy } \\
\text { stem }\end{array}$ & Decoction & Oral & 0.11 & 47.61 & 0.08 & [24] \\
\hline $\begin{array}{c}\text { Fabaceae } \\
\text { Glycine max (L.) Merr. }\end{array}$ & Soja & TIZ69 & Seed & powder & Oral & 0.46 & 36.84 & 0.34 & {$[6,19,24,33]$} \\
\hline $\begin{array}{c}\text { Lupinus angustifolius } \\
\mathrm{L}\end{array}$ & Ibaoun dokok & TIZ71 & Leaf & Infusion & Oral & 0.06 & 33.33 & 0.03 & {$[6,84]$} \\
\hline $\begin{array}{l}\text { Trigonella foenum } \\
\text { graecum L. }\end{array}$ & Tifidas/Lhalba & TAF13 & Seed & Decoction & Oral & 1.99 & 49.43 & 0.62 & $\begin{array}{c}{[5,6,19-} \\
21,24,33,38,39,42,45,48- \\
50,52,54,62,84,86]\end{array}$ \\
\hline $\begin{array}{l}\text { Juglandaceae } \\
\text { Juglans regia L. }\end{array}$ & Siwak/Grgaa & TIZ78 & Leaf & Decoction & Oral & 2.01 & 47.01 & 0.9 & {$[5,6,60,84,86]$} \\
\hline $\begin{array}{l}\text { Lamiaceae } \\
\text { Ajuga iva (L.) Schreb }\end{array}$ & $\begin{array}{l}\text { Timnra niznkad/ } \\
\text { chendgoura }\end{array}$ & TIZ80 & $\begin{array}{l}\text { Leafy } \\
\text { stem }\end{array}$ & Decoction & Oral & 0.94 & 36.11 & 0.64 & $\begin{array}{c}{[5,6,24,33,53,54,70,71,84,8} \\
6,87]\end{array}$ \\
\hline $\begin{array}{c}\text { Lavandula maroccana } \\
\text { Murbeck }^{* *}\end{array}$ & Iguiz & TON17 & $\begin{array}{l}\text { Aerial } \\
\text { parts }\end{array}$ & Decoction & Oral & 2.21 & 65.19 & 0.96 & {$[24,39]$} \\
\hline $\begin{array}{l}\text { Salvia lavandulifolia } \\
\text { Vahl. }\end{array}$ & Salmiya Tabeldit & TON20 & Leaf & Infusion & Oral & 2.22 & 59.32 & 0.96 & [61] \\
\hline Teucrium polium $L$. & $\begin{array}{c}\text { Tiwrar nizane/Touga } \\
\text { nozbar }\end{array}$ & TIZ88 & $\begin{array}{l}\text { Aerial } \\
\text { parts }\end{array}$ & Tisane & Oral & 1.99 & 48.3 & 0.95 & {$[6,39,45,74]$} \\
\hline $\begin{array}{c}\text { Malvaceae } \\
\text { Hibiscus sabdariffa L. }\end{array}$ & Lkarkadi & TSO21 & Leaf & Tisane & Oral & 0.06 & 25 & 0.03 & {$[63,84]$} \\
\hline $\begin{array}{c}\text { Oleaceae } \\
\text { Olea europaea L. }\end{array}$ & Zaytoune & TIZ94 & Leaf & Decoction & Oral & 1.71 & 51.31 & 0.95 & $\begin{array}{c}{[5,20,21,24,33,38,39,52} \\
54,62,63,84-86]\end{array}$ \\
\hline $\begin{array}{c}\text { Papaveraceae } \\
\text { Papaver rhoeas L }\end{array}$ & Gawche / Belaamen & TIZ96 & Seed & Decoction & Oral & 1.98 & 46.45 & 0.75 & {$[45,86]$} \\
\hline $\begin{array}{c}\text { Plantaginaceae } \\
\text { Globularia alypum L }\end{array}$ & $\begin{array}{l}\text { Tasselgha/Ain } \\
\text { lerneb }\end{array}$ & TON23 & Leaf & Decoction & Oral & 1.46 & 39.33 & 0.64 & {$[6,24,38,39,53,54,84,86,87]$} \\
\hline $\begin{array}{c}\text { Poaceae } \\
\text { Avena sterilis L }\end{array}$ & Waskone/ Khortal & TON27 & Seed & powder & Oral & 0.93 & 39.39 & 0.59 & No reference \\
\hline Lolium perenne L. & Ezéwane & TON29 & Seed & Decoction & Oral & 1.01 & 40.24 & 0.59 & No reference \\
\hline Zea mays $L$. & Asngar/Lkbal & TIZ102 & Seed & Decoction & Oral & 1.15 & 33.79 & 0.52 & {$[76,86]$} \\
\hline
\end{tabular}


Citation: Katiri A, Barkaoui M, Msanda F, Boubaker H (2017) Ethnobotanical Survey of Medicinal Plants Used for the Treatment of Diabetes in the Tizi n' Test Region (Taroudant Province, Morocco). J Pharmacogn Nat Prod 3: 130. doi: 10.4172/2472-0992.1000130

Page 5 of 10

\begin{tabular}{|c|c|c|c|c|c|c|c|c|c|}
\hline $\begin{array}{c}\text { Portulacaceae } \\
\text { Portulaca oleracea L. }\end{array}$ & Errajla /Tafrita & TIZ104 & $\begin{array}{l}\text { Leafy } \\
\text { stem }\end{array}$ & Decoction & Oral & 0.19 & 31.25 & 0.11 & {$[6,84,87]$} \\
\hline $\begin{array}{l}\text { Ranunculaceae } \\
\text { Nigella Sativa L. }\end{array}$ & Sanouj/Haba sawda & TSO25 & Seed & $\begin{array}{l}\text { Powder with } \\
\text { Honey }\end{array}$ & Oral & 1.58 & 45.4 & 0.54 & {$[6,54,67,68,84,86]$} \\
\hline $\begin{array}{c}\text { Rhamnaceae } \\
\text { Ziziphus lotus (L.) Lam }\end{array}$ & Azougar/Sedr- Nbeg & TIZ108 & Root & Infusion & Oral & 1.97 & 35.2 & 0.64 & {$[6,21,24,33,54,75,84,86]$} \\
\hline $\begin{array}{c}\text { Rosaceae } \\
\text { Malus communis L }\end{array}$ & Etefah & TIZ110 & Fruit & Juice & Oral & 1.03 & 29 & 0.36 & [85] \\
\hline $\begin{array}{c}\text { Prunus dulcis (Miller) } \\
\text { D.A.Webb }\end{array}$ & Loz irzagen/loz Mor & TIZ114 & Leaf & Decoction & Oral & 1.1 & 37.02 & 0.65 & {$[6,20,33,38,84,86]$} \\
\hline $\begin{array}{l}\text { Rubus ulmifolius } \\
\text { (Schott). }\end{array}$ & Tanajelt & TIZ117 & Leaf & Decoction & Oral & 1.22 & 41.08 & 0.66 & [86] \\
\hline $\begin{array}{c}\text { Sapotaceae } \\
\text { Argania spinosa }(\mathrm{L}) \\
\text { Skeels }\end{array}$ & Argan & TAF19 & Leaf & Decoction & Oral & 1.2 & 34.38 & 0.57 & {$[24,39,47,69,84]$} \\
\hline $\begin{array}{c}\text { Urticaceae } \\
\text { Urtica dioïca L }\end{array}$ & Tlamtz/Lhrayga & TIZ126 & $\begin{array}{l}\text { Leaf and } \\
\text { Seed }\end{array}$ & Decoction & Oral & 1.98 & 49.25 & 0.95 & {$[5,6,38,45,54,84,87]$} \\
\hline
\end{tabular}

"*: Endemic species of Morocco, ": Endemic species of Morocco, Algeria and the lberian Peninsula. FL\%: Fidelity Level; UV: Use Value; RFC: Relative Frequency of Citation Table 1: Plants used against diabetes in Tizi n'Test region.

\begin{tabular}{|c|c|c|c|c|c|}
\hline Species & Type of plants & Habit & Species & Type of plants & Habit \\
\hline 1-Ajuga iva (L.) Schreb. & Spontaneous & Hemicryptophyte & 21-Lolium perenne L. & Cultivated & Hemicryptophyte \\
\hline $\begin{array}{c}\text { 2-Argania spinosa (L.) } \\
\text { Skeels. }\end{array}$ & Spontaneous & Tree & 22-Lupinus angustifolius L. & Spontaneous & Herb \\
\hline 3-Aristolochia baetica L. & Spontaneous & Shrub & 23-Malus communis L. & Cultivated & Tree \\
\hline 4-Artemisia herba alba. & Spontaneous & Shrub & 24-Nerium oleander L. & Spontaneous & Subshrub \\
\hline 5-Avena sterilis L. & Spontaneous & Herb & 25-Nigella Sativa L. & Imported & Herb \\
\hline 6- Capparis spinosa L. & Spontaneous & Shrub & 26-Olea europaea L. & Cultivated & Tree \\
\hline $\begin{array}{l}\text { 7-Caralluma europaea } \\
\text { (Guss.) N.E.Br. ssp. } \\
\text { maroccana (Hooker f.) Maire. }\end{array}$ & Spontaneous & Herb & 27-Papaver rhoeas L. & Spontaneous & Herb \\
\hline 8-Cistus creticus L. & Spontaneous & Shrub & $\begin{array}{c}\text { 28-Paronychia argentea } \\
\text { Lamk. }\end{array}$ & Spontaneous & Hemicryptophyte \\
\hline 9-Cistus Laurifolius L. & Spontaneous & Shrub & 29-Periploca laevigata Ait. & Spontaneous & Shrub \\
\hline $\begin{array}{c}\text { 10-Citrullus colocynthis (L.) } \\
\text { Schrader }\end{array}$ & Imported & Geophyte & 30-Portulaca oleracea L. & Spontaneous & Herb \\
\hline $\begin{array}{c}\text { 11-Cladanthus scariosus } \\
\text { Ball. }\end{array}$ & Spontaneous & Herb & $\begin{array}{c}\text { 31-Prunus dulcis (Miller) } \\
\text { D.A.Webb. }\end{array}$ & Cultivated & Tree \\
\hline 12-Echinops spinosus L. & Spontaneous & Hemicryptophyte & $\begin{array}{l}\text { 32-Rubus ulmifolius } \\
\text { (chott). }\end{array}$ & Spontaneous & Shrub \\
\hline 13-Ephedra fragilis desf. & Spontaneous & Subshrub & $\begin{array}{c}\text { 33-Salvia lavandulifolia } \\
\text { Vahl. }\end{array}$ & Spontaneous & Shrub \\
\hline $\begin{array}{c}\text { 14-Euphorbia resinifera } \\
\text { Berg. }\end{array}$ & Imported & Subshrub & 34-Scolymus hispanicus L. & Spontaneous & Hemicryptophyte \\
\hline 15-Globularia alypum L. & Spontaneous & Shrub & 35-Teucrium polium L. & Spontaneous & Subshrub \\
\hline 16-Glycine $\max$ (L.) Merr. & Imported & Herb & $\begin{array}{l}\text { 36-Trigonella foenum } \\
\text { graecum L. }\end{array}$ & Cultivated & Herb \\
\hline 17-Hibiscus sabdariffa L. & Imported & Subshrub & 37-Urtica dioïca L. & Spontaneous & Herb \\
\hline 18-Inula viscosa Ait. & Spontaneous & Herb & 38-Zea mays L. & Cultivated & Herb \\
\hline 19-Juglans regia L. & Cultivated & Tree & 39-Ziziphus lotus (L.)Lam. & Spontaneous & Subshrub \\
\hline $\begin{array}{c}\text { 20-Lavandula maroccana } \\
\text { Murbeck L. }\end{array}$ & Spontaneous & Shrub & - & - & - \\
\hline
\end{tabular}

Table 2: Type of plants and habit.

are Artemisia herba-alba, Cistus creticus, Lavandula maroccana, Salvia lavandulifolia, Olea europaea and Urtica diö̈ca (Figure 4).

In the Tzi n'Test region, like most regions of Morocco as well as in other countries, a conflict may be established between plant use and resources conservation [35,36]. Some species suffer a high collection pressure with medicinal purposes. These factors combined with an increasing population pressure may lead to further reduction in natural habitats of the medicinal plants. Furthermore, during collection of plants, users tend to uproot the whole plant instead of collecting only the desired parts. This method of collection may seriously compromise the sustainability of medicinal species.

\section{Plant parts used, their preparation and administration}

Leaves were the most frequently used plant parts $(37.5 \%)$, followed by seeds $(22.5 \%)$, leafy stem (15\%), roots (10\%), aerial parts (7\%), fruits (5\%) and flowers (3\%) (Figure 5). The use of leaves to treat diseases is based on the fact that leaves are the main photosynthetic organs and constitute the parts relatively most easily accessible and available throughout the year [37]. The results of this study showed that aerial plant parts play an important role in herbal medicine preparation in Tzi n'Test region, agreeing with the results of studies in Morocco $[24,38,39]$ and in other countries [25,26,40-42]. Most preparations were drawn from single plant, but their mixtures were also commonly 
Citation: Katiri A, Barkaoui M, Msanda F, Boubaker H (2017) Ethnobotanical Survey of Medicinal Plants Used for the Treatment of Diabetes in the Tizi n' Test Region (Taroudant Province, Morocco). J Pharmacogn Nat Prod 3: 130. doi: 10.4172/2472-0992.1000130

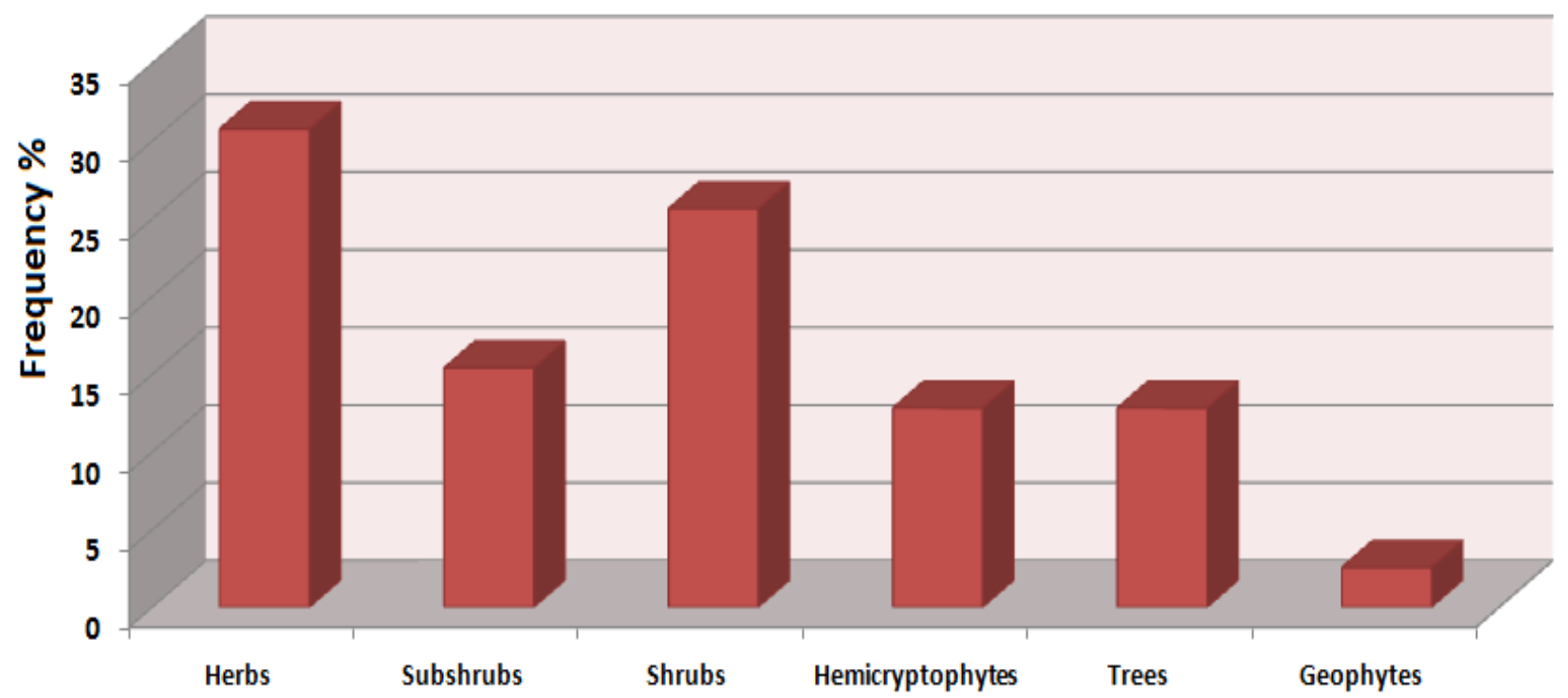

Figure 3: Growth forms (habits) of the reported medicinal plant species used for the treatment of diabetes in the Tizi n'Test region.

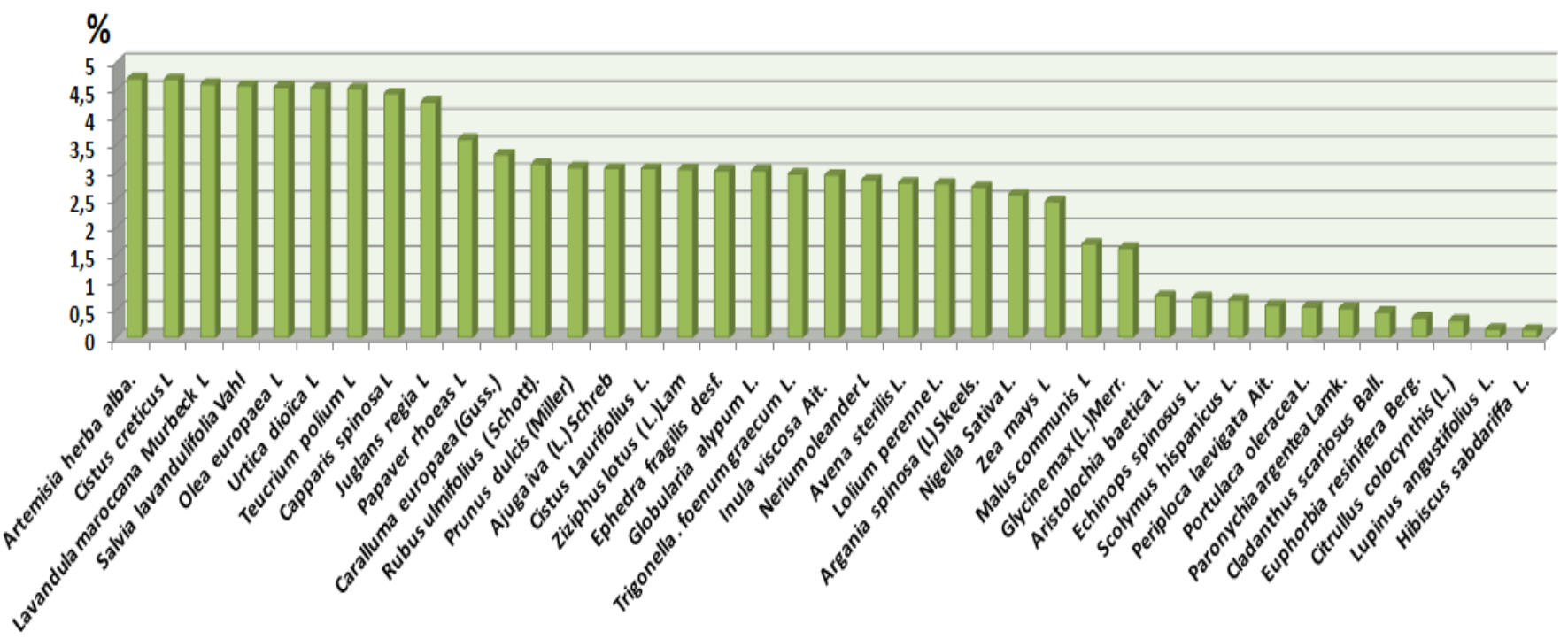

Figure 4: Use frequency of the popular medicinal plants to treat diabetes in the Tizi n'Test region (Taroudant Province).

used. Some remedies contain varying combinations of plant organs. The use of more than one plant species to prepare a remedy to treat diabetes mellitus is attributed to the additive or synergistic effects that they could have [43].

Most preparations are made with water as a solvent. Various plant parts were also mixed with oil, honey, milk or tea for enhancing their acceptability and medicinal properties (for example, powder of Nigella sativa mixed with honey). The decoction and infusion were generally the method of choice, accounting for 68.29 and $12.19 \%$ respectively, followed by powder preparation (9.76\%) (Figure 6). It was also observed that some plants were used in more than one form of preparation. Other less common ways of preparation included juice and tisane. Decoction and infusion were also the most used herbal preparations in other regions of Morocco and worldwide [5,20,21,26,33,41,44-46]. The great majority of the remedies were taken orally. Decoctions and infusions are usually drunk as teas.

\section{Ethnobotanical indices}

FL, UV and RFC values of each species are calculated from the available information. FL indicates the informants choice for a potential plant species to treat a given disease; UV determined most frequently used plant species, whereas RFC determined the most popular medicinal plants accepted by the majority of the informants for treating diabetes. FL, UV and RFC values of collected plants for the selected study area ranges between $21.43 \%$ and $77.53 \%, 0.06$ and 2.24 , 0.03 and 0.99 respectively (Table 1 ). 


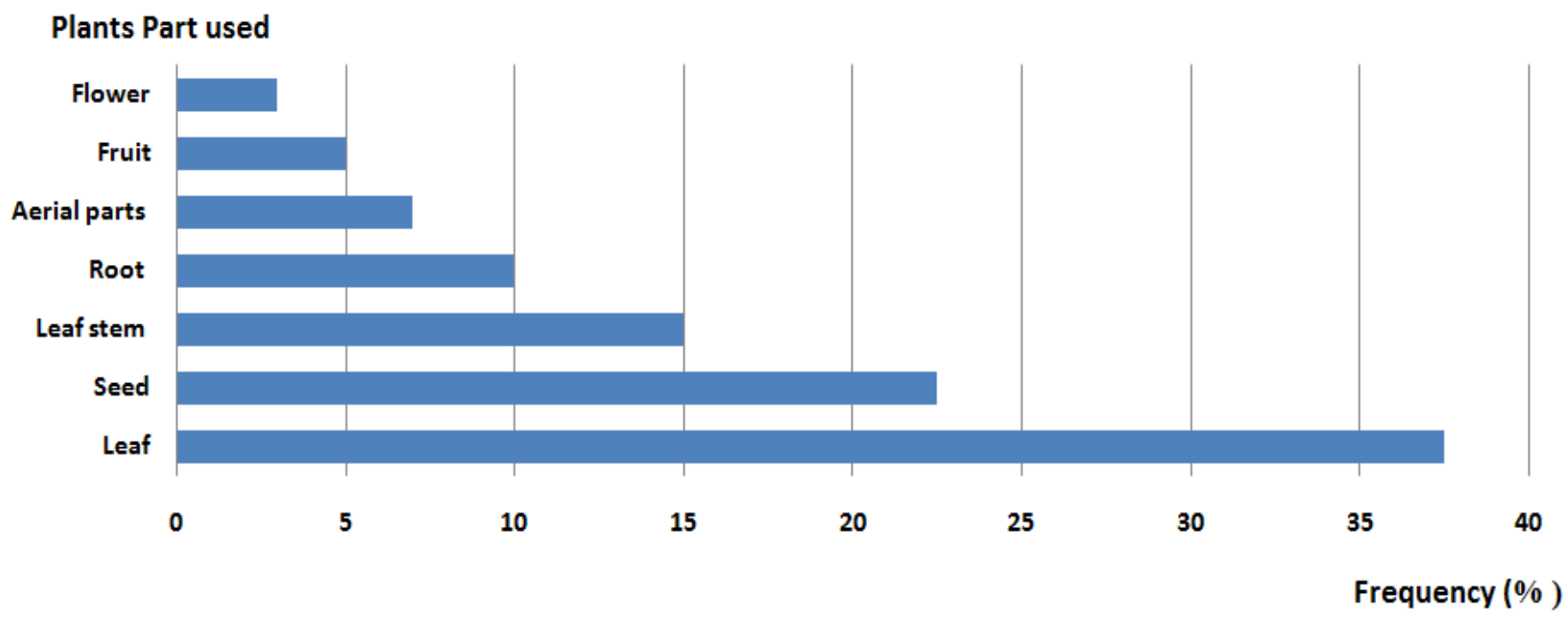

Figure 5: Frequency of plant parts reported to be used in preparation of diabetes remedies.

\section{Preparation of plants drug}

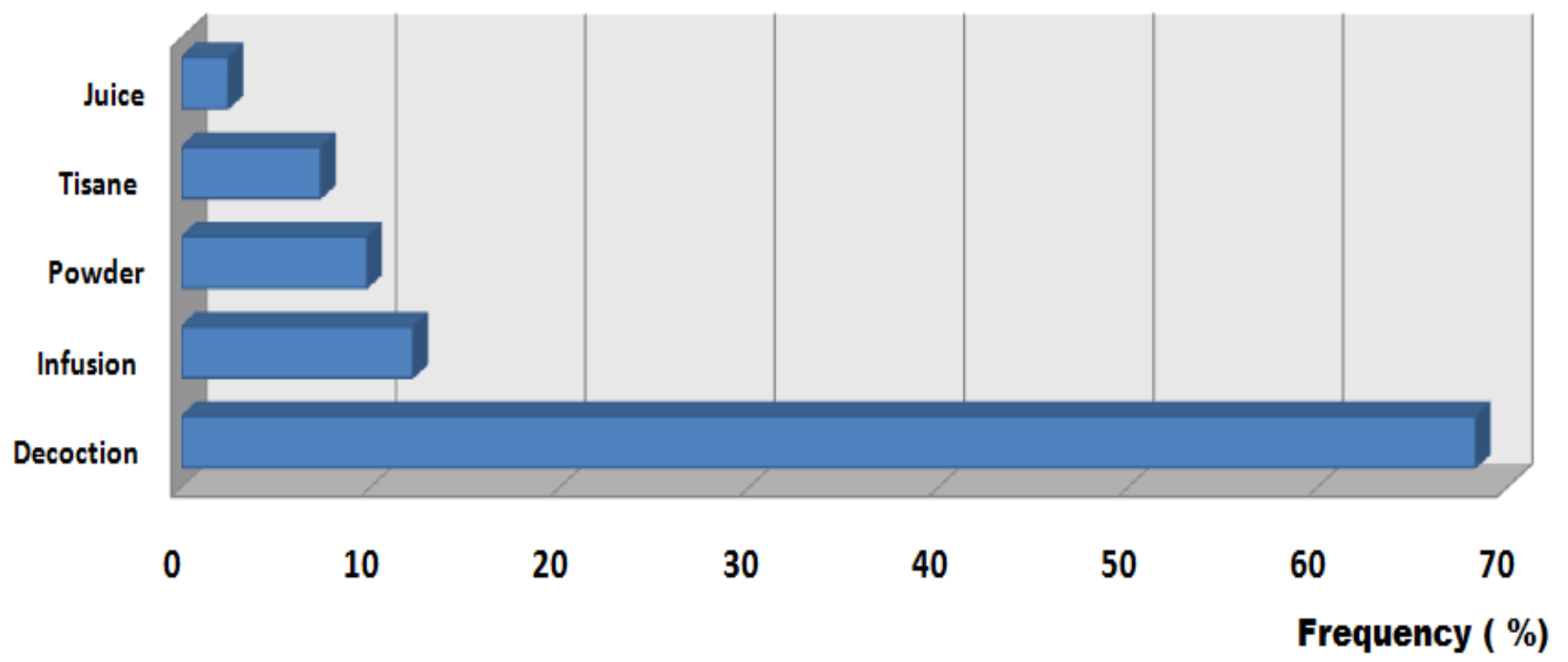

Figure 6: Frequency of methods preparation of plants drug.

To determine culturally important medicinal species in the Tizi n'Test region, FL of plants has been calculated based on use reports which have been cited by five or more informants for being used against diabetes mellitus. Of the 39 inventoried species five plants were identified with FL greater than 50\%: Artemisia herba-alba, Cistus creticus, Lavandula maroccana, Olea europaea and Salvia lavandulifolia (Table 1). Additionally, according to the calculation made on the basis of the UV, A. herba-alba, Cistus creticus, Lavandula maroccana, Capparis spinosa, Juglans regia and Salvia lavandulifolia, showed the highest use value (UV>2) (Table 1 ). The most frequently used plants to treat diabetes with high RFC (>0.5) include A. herb-alba, Capparis spinosa, Cistus creticus, Lavandula maroccana, Juglans regia, Salvia lavandulifolia, Olea europaea, Teucrium polium, Urtica dioica, etc. In the obtained results, Artemisia herba alba, Cistus creticus, Lavandula maroccana, Salvia lavandulifolia, Olea europaea and Capparis spinosa shows high values of UV and also possess high RFC. The utilization rates of these plants are higher than for any other plants, indicating the value of these plants to the community of Tizi n'Test region as a medicinal resource.

Additionally, FL indices were high for Trigonella foenum graecum (49.43\%), Euphorbia resinifera (47.61\%) and Urtica dioica (49.25\%) (Table 1).

Our results are similar to those reported in Morocco in other studies [5,19,20,33,47] where Lavandula spp., Artemisia herba alba and Trigonella foenum graecum are also used to treat diabetes mellitus. 


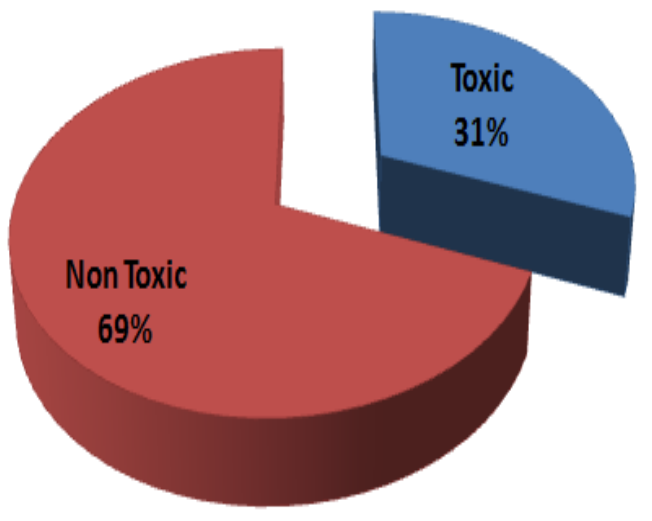

Figure 7: Percentage of toxic and non-toxic medicinal plants.

Recently, Artemisia herba-alba and Trigonella foenum graecum are also documented as the most frequently used species to treat diabetes in Southeastern Algeria [42].

Most of the plantslisted in Table 1 have been validated experimentally through in vitro and in vivo research for their hypoglycemic activity and support their traditional use in diabetes mellitus control. These species include Trigonella foenum-graecum [48-50], Artemisia herbaalba [51-69], Juglans regia [60], Lavandula maroccana [24,39], Salvia lavandulifolia [61], Olea europaea [21,24,38,39,52,54,62,63], Citrullus colocynthis [64-66], Nigella [67,68], Argania spinosa [47,69], Ajuga iva [70,71], Capparis spinosa [72], Cistus laurifolius [73], Teucrium polium [74], Ziziphus lotus [75], Zea mays [76] and Hibiscus sabdariffa [63]. To the best of our knowledge, Cistus creticus and Cladanthus scariosus are mentioned for the first time for treating diabetes.

\section{Harmful effects of medicinal plants}

Through this survey and according to bibliographical data, 31\% of the plants used to treat diabetes in the Tizi n'Test region are toxic (Figure 7). Although fortunately, most of the local Tizi n'Test people recognize these toxic plants and are very careful when using it. The main toxic plants in the Tizi n'Test region are Nerium oleander [77,78], Aristolochia baetica [78], Citrullus colocynthis [64,78,79], Lupinus angustifolius [80], Teucrium polium [78,81], Nigella sativa [78,82], Papaver rhoeas [83], Lolium perenne [78], which are still used in the treatment of diabetes diseases.

\section{Conclusion}

Our study showed that medicinal plants continue to play an important role in the primary healthcare system for the local population of the tizi n'Test region, Taroudant Province, southern Morocco. Most people in the region have little economic means to access Western medicine, and still have belief in the efficacy of herbal medicine to treat diabetes. Current study represents a useful documentation, which can contribute to preserving knowledge on the use of medicinal plants in this region. Moreover, protective measures are necessary for the conservation and preservation of the natural herbal resources, to avoid their overexploitation.

\section{Acknowledgement}

The author wishes to thank all individuals and the local informants for their commitment and dedication in sharing their valuable knowledge on medicinal plants used for diabetes treatment, including all the friends and women of the Tizi n'Test region who helped us to collect some plant samples, and we also thank Mr. Rachid Zahir, English language teacher, for his kind contribution.

\section{References}

1. Consultation WHO (1999) Definition, Diagnosis and Classification of Diabetes Mellitus and its Complications.

2. International Diabetes Federation (2015) IDF Diabetes Atlas ( $7^{\text {th }}$ edn.) International Diabetes Federation, Brussels, Belgium.

3. International Diabetes Federation (2013) IDF Diabetes Atlas (6 $6^{\text {th }}$ edn.) International Diabetes Federation, Brussels, Belgium.

4. World Health Organization (WHO) (2002) WHO launches the first global strategy on traditional medicine: Press release WHO/38, Geneva, Switzerland

5. Ziyyat A, Legssyer A, Mekhfi H, Dassouli A, Serhrouchni M, et al. (1997) Phytotherapy of hypertension and diabetes in oriental Morocco. J Ethnopharmacol 58: 45-54.

6. Bnouham M, Mekhfi H, Legssyer A, Ziyyat A (2002) Medicinal plants used in the treatment of diabetes in Morocco. J Diabetes Metab 10: 33-50.

7. Msanda F, El Aboudi A, Peltier JP (2005) Biodiversité et biogeography de l'arganeraie marocaine. Cah Agric 14: 357-364.

8. Mehdioui R, Kahoudji A (2007) Etude ethnobotanique auprès de la population riveraine de la forêt d'Amsittène: cas de la commune d'Imi n'Tlit (Province d'Essaouira). Bull Inst Scient (Rabat) Section Sci de la Vie 29: 11-20.

9. Halberstein RA (2005) Medicinal plants: historical and cross-cultural usage patterns. Ann Epidemiol 15: 686-699.

10. Al-Adhroey AH, Nor ZM, Al-Mekhali HM, Mahmud R (2010) Ethnobotanical study on some Malaysian anti-malarial plants: A community based survey. J Ethnopharmacol 132: 362-364.

11. Addo-Fordjour P, Anning AK, Akanwariwiak WG, Belford EJD, Firempong CK (2012) Medicinal plants of Ghana. In: Singh RJ (ed.) Genitic resources, chromosome engineer, and crop improvement: Medicinal plants. CRC Press, Taylor and Francis Group, LLC, USA, pp: 221-246.

12. Gonzàlez-Tejero MR, Casares-Porcel M, Casares-Porcel M, Sanchez-Rojas CP, Ramiro-Guti'errez JM, et al. (2008) Medicinal plants in the Mediterranean area: Synthesis of the project Rubia. J Ethnopharmacol 116: 341-357.

13. Fennane M, Ibn Tattou M, Mathez J, Ouyahya A, Oualidi J (1999) Flore Pratique du Maroc, Vol. 1: Pteridophya, Gymnosperme, Angiospermae (LauraceaeNeuradaceae): Manuel de Détermination Travaux de l'Institut Scientifique, Série Botanique $n^{\circ} 36$, Rabat.

14. Fennane M, Ibn Tattou M, Mathez J, Ouyahya A, Oualidi J (2007) Flore Pratique du Maroc, Vol. 2: Pteridophya, Gymnosperme, Angiospermae (LauraceaeNeuradaceae): Manuel de Détermination Travaux de l'Institut Scientifique, Série Botanique $n^{\circ} 38$, Rabat.

15. Fennane M, Ibn Tattou M, Mathez J, Ouyahya A, Oualidi J (2014) Flore Pratique du Maroc, Vol. 3: Dicotyledones (p.p.), Monocotylédones: Manuel de Détermination Travaux de l'Institut Scientifique, Série Botanique $n^{\circ} 40$, Rabat.

16. Friedman J, Yaniv Z, Dafni A, Palewitch (1986) A preliminary classification of the healing potential of medicinal plants, based on a rational analysis of an ethnopharmacological field survey among Bedouins in the Negev desert Israel. J Ethnopharmacol 16: 215-281.

17. Phillips O, Gentry AH, Reynel C, Wilkin P, Galvezdurand BD (1994) Quantitative ethnobotany and Amazonian conservation. Conserv Biol 8: 225-248.

18. Tardío J, Pardo-de-Santayana M (2008) Cultural importance indicates: a comparative analysis based on the useful wild plants of Southern Cantabria (Northern Spain). Econ Bot 62: 24-39.

19. Jouad HM, Haloui MH, Rhiouani H, El Hilaly JM, Eddouks M (2001) Ethnobotanical survey of medicinal plants used for the treatment of diabetes cardiac and renal diseases in the North centre region of Morocco (FezBoulemane). J Ethnopharmacol 77: 175-182.

20. Eddouks M, Maghani M, Lemhadri A, Ouahidi ML, Jouad H (2002) Ethnopharmacological survey of medicinal plants used for the treatment of diabetes mellitus, hypertension and cardiac diseases in the south-east region of Morocco (Tafilalet). J Ethnopharmacol 82: 97-103.

21. El-Hilaly J, Hmammouchi M, Lyoussi B (2003) Ethnobotanical studies and economic evaluation of medicinal plants in Taounate Province (Northern Morocco). J Ethnopharmacol 86: 149-158

22. Savo V, Giulia C, Maria GP, David R (2011) Folk phytotherapy of the Amalfi 
Citation: Katiri A, Barkaoui M, Msanda F, Boubaker H (2017) Ethnobotanical Survey of Medicinal Plants Used for the Treatment of Diabetes in the Tizi n' Test Region (Taroudant Province, Morocco). J Pharmacogn Nat Prod 3: 130. doi: 10.4172/2472-0992.1000130

Coast (Campania, Southern Italy). J Ethnopharmacol 135: 376-392.

23. Packer J, Brouwer N, Harrington D, Gailkwad J, Heron R, et al. (2012) An ethnobotanical study of medicinal plants used by the Yaegl Aboriginal community in northern New South Wales, Australia. J Ethnopharmacol 139: 244-255

24. Abouri M, El-Mousadik A, Msanda F, Boubaker H, Saadi B, et al. (2012) An ethnobotanical survey of medicinal plants used in the Tata Province, Morocco. J Med Plant Res 1: 099-123.

25. Kpodar MS, Lawson-Evi P, Bakoma B, Eklu-Gadegbeku K, Agbonon A, et al. (2015) Ethnopharmacological survey of plants used in the treatment of diabetes mellitus in south of Togo (Maritime Region). J Herbal Med 5: 147-152.

26. Kadir MF, Bin Sayeed MS, Shams T, Mia MMK (2012) Ethnobotanical survey of medicinal plants used by Bangladeshi traditional health practitioners in the management of diabetes mellitus. J Ethnopharmacol 144: 605-611.

27. Tag H, Kalita P, Dwivedi P, Das AK, Namsa ND (2012) Herbal medicines used in the treatment of diabetes mellitus in Arunachal Himalaya, northeast, India. J Ethnopharmacol 141: 786-795.

28. Benitez G, Gonzalez-Tejero MR, Motero-Mesa J (2010) Pharmaceutical ethnobotany in the western part of Granada province (southern Spain): Ethnopharmacological synthesis. J Ethnopharmacol 129: 87-105.

29. Dey A, Gupta B, Nath De J (2012) Traditional phytotherapy against skin diseases and in wound, healing of the tribes of Purulia district, West Bengal, India. J Med Plant Res 6: 4825-4831.

30. Raja D, Blanché C, Vallès J (1997) Contribution to be knowledge of the pharmaceutical ethnobotany of the Segarra region (Catalonia, Iberian Peninsula). J Ethnopharmacol 57: 149-160.

31. Merzouki A, Ed-derfoufi F, Molero Messa J (2000) Contribution to the knowledge of Rifian traditional medicine II: Folk medicine in Ksar Lakbir district (NW Morocco). Fitoterapia 71: 278-307.

32. Novais MH, Santos I, Mendes S, Pinto-Gomes C (2004) Studies on pharmaceutical ethnobotany in Arrabida Natural Park (Portugal). J Ethnopharmacol 93: 183-195.

33. Tahraoui A, El-Hilaly J, Israili ZH, Lyoussi B (2007) Ethnopharmacological survey of plants used in the traditional treatment of hypertension and diadetes in southeastern Morocco (Errachidia province). J Ethnopharmacol 110: 105-117.

34. Ugulu I, Baslar S, Yorek N, Dogan Y (2009) The investigation and quantitative ethnobotanical evaluation of medicinal plants used around Izmir province, Turkey. J Med Plants Res 3: 345-367.

35. Sheldon JW, Balick M, Laird S (1998) Is using medicinal plants compatible with conservation? Plant Talk 13: 29-31.

36. Agelet A, Vallès J (2001) Studies on pharmaceutical ethnobotany in the region of Pallars (Pyrenees, Catalonia, Iberian Peninsula). Part I. General results and new or very rare medicinal plants. J Ethnopharmacol 77: 57-70.

37. Fézan HT, Guy MI, Kohué CC, Mahou CHB (2008) Études de quelques plantes thérapeutiques utilisées dans le traitement de l'hypertension artérielle et du diabète: deux maladies émergentes en Côte d'Ivoire. Sci Nature 5: 39-48.

38. Jamila E, Mostafa E (2014) Ethnobotanical survey of medicinal plants used by people in oriental Morocco to manage various ailments. J Ethnopharmacol 154: 76-87.

39. Saadi B, Msanda F, Boubaker H (2013) Contributions of folk medicine knowledge in South-western Morocco: The case of rural communities of Imouzzer Ida Outanane Region. J Med Plant Res 2: 135-145.

40. Katemo M, Mpiana, Mbala PT, Mihigo BM, Ngbolua SO, et al. (2012) Ethnopharmacological survey of plants used against diabetes in Kisangani city (DR Congo). J Ethnopharmacol 144: 39-43.

41. Nowbandegani AS, Kiumarcy S, Rahmani F, Dokouhaki M, Khademian S, et al. (2015) Ethnopharmacological knowledge of Shiraz and Fasa in Fars region of Iran for diabetes mellitus. J Ethnopharmacol 172: 281-287.

42. Telli A, Esnault MA, Ould E, Hadj Khelil A (2016) An ethnopharmacological survey of plants used in traditional diabetes treatment in south-eastern Algeria (Ouargla province). J Arid Environ 127: 82-92.

43. Bussman RW, Sharon D (2006) Traditional medicinal plant use in Northern Peru: tracking two thousand years healing culture. J Ethnobiol Ethnomed 2: 47.
44. Afolayan AJ, Grierson DS, Mbeng WO (2014) Ethnobotanical survey of medicinal plants used in the management of skin disorders among the Xhosa communities of the Amathole District, Eastern Cape, South Africa. J Ethnopharmacol 153: 220-232.

45. Bahmani M, Zargaran A, Rafieian Kopaei, Saki K (2014) Ethnobotanical study of medicinal plants used in the management of diabetes mellitus in the Urmia, Northwest Iran. Asian Pac J Trop Med 7: 348-354.

46. Urso V, Signorini MA, Tonini M, Bruschi P (2016) Wild medicinal and food plants used by communities living in Mopane woodlands of southern Angola: Results of an ethnobotanical field investigation. J Ethnopharmacol 177: 126-139.

47. Mohamed B, Said B, Wafaa B, Abdelkhaleq L, Abderrahim Z, et al. (2008) Antidiabetic Activity Assessment of Argania spinosa Oil. J Complement Integr Med 5: 1553-3840.

48. Ali L, Azad Khan AK, Hassan Z, Mosihuzzaman M, Nahar N, et al. (1995) Characterization of the Hypoglycemic Effects of Trigonella foenum-graecum Seed. Planta Med 61: 358-360.

49. Hamza N, Berke B, Cheze C, Marais S, Lorrain S, et al ( 2015) Effect of Centaurium erythraea Rafn, Artemisia herba-alba Asso and Trigonella foenumgraecum L. on liver fat accumulation in C57BL/6J mice with high-fat dietinduced type 2 diabetes. J Ethnopharmacol 171: 4-11.

50. Renuka C, Ramesh N, Saravanan K (2009) Evaluation of the antidiabetic effect of Trigonella foenum-graecum seed powder on alloxan-induced diabetic albino rats. Int J of Pharm Tech Res 1: 1580-1584.

51. Al-Khazraji SM, Al Shamaony LA, Tawaij HA (1993) Hypoglycaemic effect of Artemisia herba-alba Asso. I.Effect of different parts and influence of the solvent on hypoglycaemic activity. J Ethnopharmacol 40: 163-166.

52. Bousta D, Boukhira S, Aafi A, Ghanmi M, El-Mansouri L (2014) Ethnopharmacological Study anti-diabetic medicinal plants used in the MiddleAtlas region of Morocco (Sefrou region). J Pharm Res Health Sci 2: 75-79.

53. Khabbach A, Libiad M, Ennabili A, Bousta D (2012) Medicinal and cosmetic use of plants from the province of Taza, Northern Morocco. Boletin Latinoamericano y del Caribe de Plantas Medicinales y Aromáticas 11: 46-60.

54. Azzi R, Djaziri R, Lahfa F, Sekkal FZ, Benmehdi H, et al. (2012) Ethnopharmacological survey of medicinal plants used in the traditional treatment of diabetes mellitus in the North Western and South Western Algeria. J Med Plant Res 6: 2041-2050.

55. Al-Waili NS (1988) Artemisia herba-alba and diabetes mellitus. Clin Exp Pharmacol Physiol 15: 497.

56. Twaij HA, Al-Badr AA (1988) Hypoglycemic activity of Artemisia herba-alba. J Ethnopharmacol 24: 123-126.

57. Al-Shamaony L, Al-Khazraji SM, Twaij HA (1994) Hypoglycemic effect of Artemisia herba-alba. II. Effect of a valuable extract on some blood parameters in diabetic animals. J Ethnopharmacol 43: 167-171.

58. Awad NE, Seida AA, El-Khayat Z, Shaffie N, Ahmed M, et al. (2012) Hypoglycemic Activity of Artemisia herba-alba (Asso.) used in Egyptian Traditional Medicine as Hypoglycemic Remedy. J Appl Pharmaceut Sci 2: 30-39.

59. Parkami MR, Kargar Jahromy $\mathrm{H}$, Mahmoudi Teimourabad S, Bathaee SA Heidary Y, et al. (2013) A study on the effectiveness of the hydroalcoholic extract of Artemisia herba-alba On blood glucose, body weight, testis weight and testicular volume variations of type I diabetic rats using streptozotocin. Int J Biol Pharm Allied Sci 2: 1270-1281.

60. Sarahroodi S, Rasekh Kmali-Nejad HR, Safaeian L (2009) Water extract of Juglans regia $L$ and diabetes mellitus in Iranian traditional medicine. Qom Univ Med Sci J 3: 19-24.

61. Jiménez I, Jiménez J, Gámez MJ, González M, Sánchez De Medina F, et al. (1995) Effects of Salvia lavandulifolia Vahl. ssp. Oxyodon extract on pancreatic endocrine tissue in streptozotocin-diabetic rats. Phytother Res 9: 536-537.

62. Durmuskhahya C, Özturk M (2013) Ethnobotanical Survey of Medicinal Plants Used for the Treatment of Diabetes in Manisa, Turkey. Sains Malaysiana 42 1431-1438.

63. Arulselvan $\mathrm{P}$, Amynurliyana $\mathrm{AH}$, Karthivashan $\mathrm{G}$, Firdaus $\mathrm{AM}$, Syafiq $\mathrm{AM}$, et al. (2014) Antidiabetic therapeutics from natural source: A systematic review. J Biomed Prev Nutr 4: 607-617.

64. Abdel-Hassan IA, Abdel-Barry JA, Mohammeda ST (2000) The hypoglycaemic and antihyperglycaemic effect of Citrullus colocynthis fruit acqueous extrat in 
Citation: Katiri A, Barkaoui M, Msanda F, Boubaker H (2017) Ethnobotanical Survey of Medicinal Plants Used for the Treatment of Diabetes in the Tizi n' Test Region (Taroudant Province, Morocco). J Pharmacogn Nat Prod 3: 130. doi: 10.4172/2472-0992.1000130

Page 10 of 10

normal and alloxan diabetic rabbits. J Ethnopharmacol 71: 325-350.

65. Fallah HH, Darvishzadeh F, Heshmat R, Jafariazar Z, Raza M, et al. (2009) The clinical investigation of Citrullus colocynthus schrad fruit in treatment of type II diabetic patients: A randomized, double blind, placebo-controlled clinical trial. J Phytother Res 23: 1186-1189.

66. Atole SK, Jangle CR, Philip P, Rekhe DS, Aghav DV, et al. (2009) Safety Evaluation Studies of Citrullus Colocynthis for diabetes in Rats. J Vet World 2: $423-425$.

67. Al-Hader AA, Aqel M, Hassan Z (1993) Hypoglycemic effects of the volatile oil of Nigella Sativa seeds. Int J Pharmacogn 31: 96-100.

68. Bamosa AO, Kaatabi H, Lebda F, Al elq A, Al-Sultan A (2010) Effect of Nigella Sativa seeds on the glycemic control of patients with type 2 diabetes mellitus. Indian J Pharmacol 54: 344-354.

69. Samira S, Noël J, Charrouf Z, Hamid A, Haddad PS (2006) Insulin-sensitizing and Anti-proliferative Effects of Argania spinosa Seed Extracts. J Evid Based Complement Alter Med 3: 317-327.

70. El-Hilaly J, Lyoussi B (2002) Hypoglycaemic effect of the lyophilized aqueous extrat of Ajuga iva in normal and Streptozotocin induced diabetic rats. J Ethnopharmacol 80: 109-113.

71. Dalila C, Fairouz S, Abdelhak R, Kenza A (2013) Activité hypoglycémique de l'extrait aqueux d'Ajuga iva L. schreber chez les rats diabétiques induite par l'alloxane. J Afr Sci 9: 120-127.

72. Hassan FH, Shirin HR, Neda N, Ramin H, Farahnaz KS, et al. (2013) Capparis spinosa L. (Caper) fruit extrait in treatment of type 2 diabetic patient: A randomized double-blind placebo-controlled clinical trial. J Complement Ther Med 21: 447-452.

73. Orhan N, Aslan M, Süküroğlu M, Deliorman Orhan D (2013) In vivo and in vitro antidiabetic effect of Cistus laurifolius $L$. and detection of major phenolic compounds by UPLC-TOF-MS analysis. J Ethnopharmacol 146: 859-865.

74. Parisa H, Siamak S (2012) Preventive effect of Teucrium polium on learning and memory deficits in diabetic rats. Med Sci Monit 18: 41-46.

75. Benammar C, Baghdad C, Belarbi M, Subramaniam S, Hichami A (2014) Antidiabetic and Antioxidant Activities of Zizyphus lotus L. Aqueous Extracts in
Wistar Rats. J Nutr Food Sci S8: 004.

76. Suzuki R, OkadaY, Okuyama T (2003) Two flavones C-glycosides from the style of Zea mays with glycation inhibitory activity. J Nat Prod 66: 564-565

77. Eddouks M, Ouahidi ML, Farid O, Moufid A, Khalidi A, et al. (2007) The use of medicinal plants in the treatment of diabetes in Morocco. Phytother 5: 194-203.

78. Bellakhdar J (1997) La pharmacopé marocaine traditionnelle. Médecine arabe ancienne et savoirs populaires, Paris-Rabat.

79. Al-Ghaithi F, El-Ridi MR, Adeghate E, Amiri MH (2004) Biochemical effects of Citrullus colocynthis in normal and diabetic rats. Mol Cell Biochem 261: 143-149.

80. Stobiecki M, Blaszczyk B, Kowalczyk-Bronisz SH, Gulewicz K (1993) The toxicity of seed extracts and their fractions from Lupinus angustifolius $\mathrm{L}$. and Lupinus albus L. J Appl Toxicol 3: 347-352.

81. Abu Sitta Kawther H, Shomah Maha S, Abdulazim SS (2009) Hepatotoxicity of Teucrium polium tea: supporting evidence in mice models. Aust $\mathrm{J}$ Med Herbal 21: 106-109.

82. Zaoui A, Cherrah Y, Mahassini N, Alaoui K, Amarouch H, et al. (2002) Acute and chronic toxicity of Nigella sativa fixed oil. Phytomedicine 9: 69-74.

83. Soulimani R, Younos C, Jarmouni-Idrissi S, Bousta D, Khallouki F, et al. (2001) Behavioral and pharmaco-toxicological study of Papaver rhoeas L. in mice. J Ethnopharmacol 74: 265-274

84. Benkhnigue O, Ben Akka F, Salhi S, Fadli M, Douira A, et al. (2014) Catalogue des plantes médicinales utilisées dans le traitement du diabète dans la région d'Al Haouz-Rhamna (Maroc). J Anim Plant Sci 23: 3539-3568.

85. Noureddine B, Elhafian M, Rochdi A, Zidane L (2014) Étude floristique et ethnobotanique de la flore médicinale du Haut Atlas oriental (Haute Moulouya). J Appl Biosci 78: 6771-6787.

86. Allali H, Benmehdi H, Dib MA, Tabti B, Ghalem S, et al. (2008) Phytotherapy of Diabetes in West Algeria. Asian J Chem 20: 2701-2710.

87. El Rhaffari L, Zaid A (2000) Pratique de la phytothérapie dans le sud-est du Maroc (Tafilalet). Un savoir empirique pour une pharmacopée rénovée. Eur Cong Ethnopharmacol. 